JOURNAL OF

SYNCHROTRON

RADIATION

ISSN 1600-5775

Received 11 May 2019

Accepted 24 June 2019

Edited by M. Yamamoto, RIKEN SPring-8

Center, Japan

\# These authors contributed equally to this work.

Keywords: BioStruct-Africa; structural biology; neglected tropical diseases; capacity building; synchrotron; remote data collection; African Light Source.

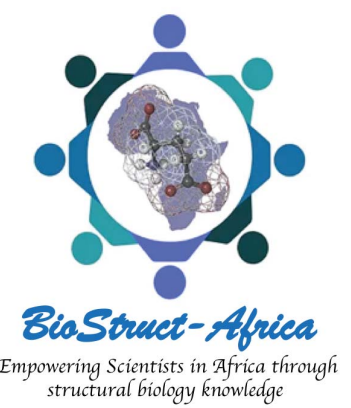

(C) 2019 International Union of Crystallography

\section{BioStruct-Africa: empowering Africa-based scientists through structural biology knowledge transfer and mentoring - recent advances and future perspectives}

\author{
Emmanuel Nji, ${ }^{\mathrm{a}, \mathrm{b}} *$ Daouda A. K. Traore, ${ }^{\mathrm{c}, \mathrm{d}, \mathrm{e}, \mathrm{f}} \neq$ Mama Ndi, ${ }^{\mathrm{a}} \neq$ Carolyn A. Joko ${ }^{\mathrm{g}} \neq$ and \\ Declan A. Doyle ${ }^{\text {h }}$
}

${ }^{a}$ Centre for Biomembrane Research, Department of Biochemistry and Biophysics, Stockholm University, SE-106 91 Stockholm, Sweden, ${ }^{\mathbf{b}}$ Drug Discovery, Confo Therapeutics, Technologiepark 94, 9052 Ghent (Zwijnaarde), Belgium, ${ }^{\mathrm{c}}$ Department of Biochemistry and Molecular Biology, Infection and Immunity Program, Monash Biomedicine Discovery Institute, Monash University, Clayton, VIC 3800, Australia, ${ }^{\mathbf{d}}$ Faculté des Sciences et Techniques, Université des Sciences, des Techniques et des Technologies de Bamako (USTTB), BP E3206, Bamako, Mali, 'e Life Sciences Group, Institut LaueLangevin, 71 Avenue des Martyrs, 38042 Grenoble Cedex 9, France, 'School of Life Sciences, Faculty of Natural Sciences, Keele University, Staffordshire ST5 5BG, UK, ${ }^{\mathrm{g}}$ Faculty of Science and Engineering, Åbo Akademi University, Turku, Finland, and ${ }^{\mathrm{h}}$ Biological Sciences, University of Southampton, Southampton SO17 1BJ, UK.

${ }^{*}$ Correspondence e-mail: emmanuel.nji@dbb.su.se

Being able to visualize biology at the molecular level is essential for our understanding of the world. A structural biology approach reveals the molecular basis of disease processes and can guide the design of new drugs as well as aid in the optimization of existing medicines. However, due to the lack of a synchrotron light source, adequate infrastructure, skilled persons and incentives for scientists in addition to limited financial support, the majority of countries across the African continent do not conduct structural biology research. Nevertheless, with technological advances such as robotic protein crystallization and remote data collection capabilities offered by many synchrotron light sources, X-ray crystallography is now potentially accessible to Africa-based scientists. This leap in technology led to the establishment in 2017 of BioStructAfrica, a non-profit organization (Swedish corporate ID: 802509-6689) whose core aim is capacity building for African students and researchers in the field of structural biology with a focus on prevalent diseases in the African continent. The team is mainly composed of, but not limited to, a group of structural biologists from the African diaspora. The members of BioStruct-Africa have taken up the mantle to serve as a catalyst in order to facilitate the information and technology transfer to those with the greatest desire and need within Africa. BioStruct-Africa achieves this by organizing workshops onsite at our partner universities and institutions based in Africa, followed by post-hoc online mentoring of participants to ensure sustainable capacity building. The workshops provide a theoretical background on protein crystallography, hands-on practical experience in protein crystallization, crystal harvesting and cryocooling, live remote data collection on a synchrotron beamline, but most importantly the links to drive further collaboration through research. Capacity building for Africa-based researchers in structural biology is crucial to win the fight against the neglected tropical diseases, e.g. ascariasis, hookworm, trichuriasis, lymphatic filariasis, active trachoma, loiasis, yellow fever, leprosy, rabies, sleeping sickness, onchocerciasis, schistosomiasis, etc., that constitute significant health, social and economic burdens to the continent. BioStructAfrica aims to build local and national expertise that will have direct benefits for healthcare within the continent.

\section{Introduction}

Structural biology focuses on determining the molecular details of macromolecules (proteins, DNA and RNA) in order 
to understand how they perform their functions. Structural biology has been proven time and time again to be key to our understanding of how disease-causing alterations either cause the disease state or circumvent our body's ability to fight back (Teng et al., 2009; Yates \& Sternberg, 2013; Nishi et al., 2013; Wei et al., 2010). Multiple structures under different conditions such as the apo-forms, with bound ligands, mutant forms and protein/protein or protein/nucleic acid complexes provide snapshots of the structural transitions that all macromolecules undergo during their normal and/or disease states (Ma et al., 2002). For example, sickle cell anaemia, which affects 250000 new-born babies annually in the world, of which $75-80 \%$ are from Africa (Stephen et al., 2018), is caused by a change in the structure of the protein haemoglobin that is located in red blood cells (Stephen et al., 2018). A surprisingly minor alteration causes the haemoglobin proteins to polymerize which ultimately has a large effect on the structure of the red blood cells making them fragile and prone to breakage (DiezSilva et al., 2010); this is believed to have a partial protective effect against Plasmodium falciparum malaria (Elguero et al., 2015; Lansche et al., 2018). In addition to general anaemia, the altered red blood cell shape causes blockages in small capillaries throughout the body, preventing the delivery of oxygen and thus hypoxia to local cellular regions resulting in the adverse effects suffered by the patient (Mohanty et al., 2014). Structural biology is well placed to help with the design of small molecules that could inhibit haemoglobin polymerization in sickle cell patients.

Unfortunately, up to now Africa has not come to mind as a hub for innovation and scientific discovery. Research carried out in Africa contributes $<2 \%$ of all new global scientific knowledge (UNESCO, 2015). Some of the major challenges hindering advancements in science in this region include the lack of adequate infrastructure, skilled personnel and limited financial support or incentives for scientists (Miah \& Omar, 2012). African scientists willing to stay on the continent or those in the diaspora willing to return are faced with the stark reality of the resource gap between Africa and high-income countries. Although daunting, the situation is changing. Initiatives such as that of the African Academy of Sciences have set up a blueprint for funding and investment strategies to foster research excellence in Africa (https://aesa.ac.ke/). Moreover, a central aspiration of the Africa 2063 agenda is 'an Africa, whose development is people-driven, relying on the potential of African people, especially its women and youth'. This aspiration speaks of the ownership of our development through investment in education, access to technology and opportunities for the children, youth and women of Africa (Addaney, 2018). In 2014, UNESCO declared the International Year of Crystallography, which paved the way for several initiatives such as the IUCr OpenLabs to help raise awareness for crystallography in Africa (UNESCO, 2015). Building on these initiatives, in 2017 BioStruct-Africa was established with a focus on macromolecular structural biology, a year after the first Pan-African conference on crystallography was held at the University of Dschang, Cameroon.
The teaching and mentoring of Africa-based scientists to become world-class structural biologists would generate research aimed directly at the fight against neglected tropical diseases (NTDs) (Singer et al., 2007). Combating NTDs is integral in realizing the United Nations' sustainable development goals (SDGs) (Njim \& Aminde, 2017; Fitzpatrick \& Engels, 2016; Addisu et al., 2019; Bangert et al., 2017; Fitzpatrick et al., 2017). Thus, BioStruct-Africa's initiative is in line with the United Nations' SDGs for 2030 (DESA, 2016; United Nations Department of Economic and Social Affairs, 2017, 2018). Clearly the drive is to ensure good health and well being (SDG-3), foster quality education (SDG-4) and promote partnerships and collaborations with other institutions within and outside of Africa (SDG-17). These tenets are also important in the achievement of all other developmental goals. In 2002, the World Health Organization (WHO) released a report titled 'Genomics and World Health' which highlighted the potentials of genomics in solving the inequality in global health (WHO, 2002). Genomes are the basis, blueprints, of all life, but it is the proteins that they code for that bring them to life as it is these proteins that build, protect, replicate and regulate all genomic functions. Biotechnology has also been implicated in solving the health problems in low- and middle-income countries (Singer et al., 2007; Acharya et al., 2004; Singer \& Daar, 2001; Daar et al., 2007; Thorsteinsdóttir et al., 2004), and such proposals have been investigated in a qualitative study upon recommendation by WHO as a means of improving the problem (Daar et al., 2002). Understanding of proteins' structure and function is essential for the output of biotechnology. These proposals include modified molecular technologies for affordable, simple diagnosis of infectious diseases, recombinant technologies to develop vaccines against infectious diseases, technologies for more efficient drug and vaccine delivery systems, improve sanitation, clean water and bioremediation, and sequencing pathogen genomes to understand their biology, and the identification of new antimicrobials (Daar et al., 2002). Investment in structural biology is well placed to help realize these goals (Singer et al., 2007). What is required is a concerted effort to build the expertise, skills and knowledge of Africabased scientists in order to respond to global health issues while at the same time helping to eliminate the health inequalities across the world, particularly in low- and middleincome countries. This is because the world is a global village an outbreak of any infectious disease can easily be transmitted from one country to another, such as the recent outbreaks of the deadly Ebola and Zika viruses (Reperant \& Osterhaus, 2017). The world has been quick and generous when dealing with the clinical issues related to severe disease outbreaks (https://www.who.int/csr/disease/ebola/funding/en/), but it is well recognized that emphasis on research funding on diseases present in Africa (NTDs) is lacking (Johnston et al., 2014). Africans have the potential, the desire, the focus and, most importantly, the need to tackle these neglected diseases. Such a successful approach will only happen in partnership with the rest of the world as the modern interconnected world means that we are all at risk as diseases are no longer a local, country 
or even localized to a single continent. What is required is the leadership and foresight to build and expand organizations such as BioStruct-Africa that puts the fight against neglected diseases in the hands of committed, talented individuals working in Africa. It has been said many times 'give a man a fish and he can feed his family for a day but give him a net and he can feed them for a lifetime'. This statement holds true when considering structural biology and the impact it can have on the lives of millions throughout Africa.

\section{2. 'The poverty gap is a technology gap' - bridging the gap via synchrotron remote access}

Despite the remarkable progress in single-particle cryo-electron microscopy (cryo-EM), X-ray crystallography still remains one of the most powerful tools used to unravel the structures of biological macromolecules to date (Cheng et al., 2015; Fernandez-Leiro \& Scheres, 2016). Indeed, both methods can complement each other (Wang \& Wang, 2017). However, X-ray crystallography is more developed and is now much more accessible than cryo-EM. To date, Africa lacks a synchrotron X-ray crystallography facility that generates sufficiently intense $\mathrm{X}$-rays upon which biological samples can be exposed and diffraction data collected and analysed. Furthermore, most African research groups do not have the resources to travel to overseas synchrotron sources. Circumventing this major issue, synchrotrons around the world have now developed capabilities for remote data collection (https:// www.diamond.ac.uk/, https://www.esrf.eu/, https://www.aps.anl. gov/, https://www.psi.ch/en/sls, https://www.maxiv.lu.se/ etc.), thus significantly reducing the associated expenses. Unfortunately, most Africa-based researchers are not aware of these advances and lack the technical know-how to make use of these synchrotron remote facilities. BioStruct-Africa seeks to raise awareness as well as to train and continually mentor African-based researchers in structural biology, protein production, crystallization, remote data collection, processing, analysis, structure determination and exploitation of the three-dimensional structures of biological macromolecules. To the best of our knowledge, BioStruct-Africa is the only organization providing hands-on training workshops and post-hoc online mentoring that focus on enhancing structural biology practical knowledge and prolificacy in data collection using synchrotron sources in west, east and central Africa that are too often ignored. Indeed, one of the major challenges faced by young scientists in Africa in their research is the lack of appropriate mentorship (Kumwenda et al., 2017). Therefore, BioStruct-Africa is providing an opportunity for students and researchers that is not currently accessible in the majority of African research settings. BioStruct-Africa's pedagogical principle is grounded in the concept of knowledge transfer from researchers within our team to the researchers working in Africa. For emerging laboratories with limited funding, BioStruct-Africa's innovative approach allows African universities and institutions to keep abreast of the knowledge in the field without the expense of travelling abroad. This approach can easily be extended to a wide range of research fields such as agriculture, biomedicine, geology, environmental eco-systems science, energy, entomology, material sciences, diffraction physics, inorganic and industrial materials, structural chemistry, etc.

\section{Recent advances}

\subsection{Framework of the BioStruct-Africa training workshops}

BioStruct-Africa recently conducted hands-on training in structural biology at the University of Ghana in January 2019. The workshops primarily focused on the practical aspects of protein crystallization, vapour diffusion, crystal harvesting, cryo-cooling and, finally, remote X-ray diffraction data collection on a synchrotron light source [Diamond Light Source Ltd (DLS), UK]. The workshop was structured as described below.

3.1.1. Introductory lectures. Three lectures were given. Firstly, a keynote lecture by a respected eminent figure in the field, Professor Sir Tom Blundell from Cambridge University, UK, entitled 'A short history of structural biology' [Fig. 1(a)]. Professor Blundell inspired the participants by describing some of the pioneers of crystallography: Bernal, Hodgkin and Perutz in the 1930s historically, then his experiences with Dorothy Hodgkin in the 1960s and writing the book 'Protein Crystallography' in the early 1970s as well as the impacts over the past five decades. This was followed by a lecture on protein expression, purification and crystallization by Professor WolfDieter Schubert from the University of Pretoria, South Africa [Fig. 1(b)]. The final lecture was delivered by Dr Ralf Flaig, Principal Beamline Scientist on the MX beamline I04 at DLS, entitled 'Practical data collection at a synchrotron, pre and post beam time - what can I do?' [Fig. 1(c)].

3.1.2. Hands-on training. There were 21 participants, including $\mathrm{PhD}$ students, post-doctoral researchers and early career scientists (mainly from Ghana and the surrounding countries). The demographic distribution of participants demonstrates the importance of training locally to build expertise. The hands-on training consisted of three parts. Firstly, Dr Emmanuel Nji and Mr Mama Ndi (BioStructAfrica/Department of Biochemistry and Biophysics, Stockholm University), Dr Daouda Traore (BioStruct-Africa/ Monash University, Melbourne, Australia) and Professor Richard Garratt (University of Sao Paolo, Brazil) provided teaching on protein crystallization. This part of the workshop began with an introductory lecture on the concepts of vapour diffusion crystallization by Dr Daouda Traore [Fig. 2(c)]. There were 11 participants who continued to the second part of the workshop [Figs. 2(b), 2(d) and 2(e)]. The number was a result of the focus switching to researchers only working with biological macromolecules. The reduced numbers demonstrate the need for the potential expansion of training into the other research fields as outlined above. Secondly, the workshop covered protein crystal imaging and harvesting performed by Dr Emmanuel Nji, Mr Mama Ndi, Dr Daouda Traore, Dr Ralf Flaig and Professor Richard Garratt [Figs. $2(b), 2(d)$ and $2(e)]$. To ensure that the training was produc- 


\section{teaching and education}

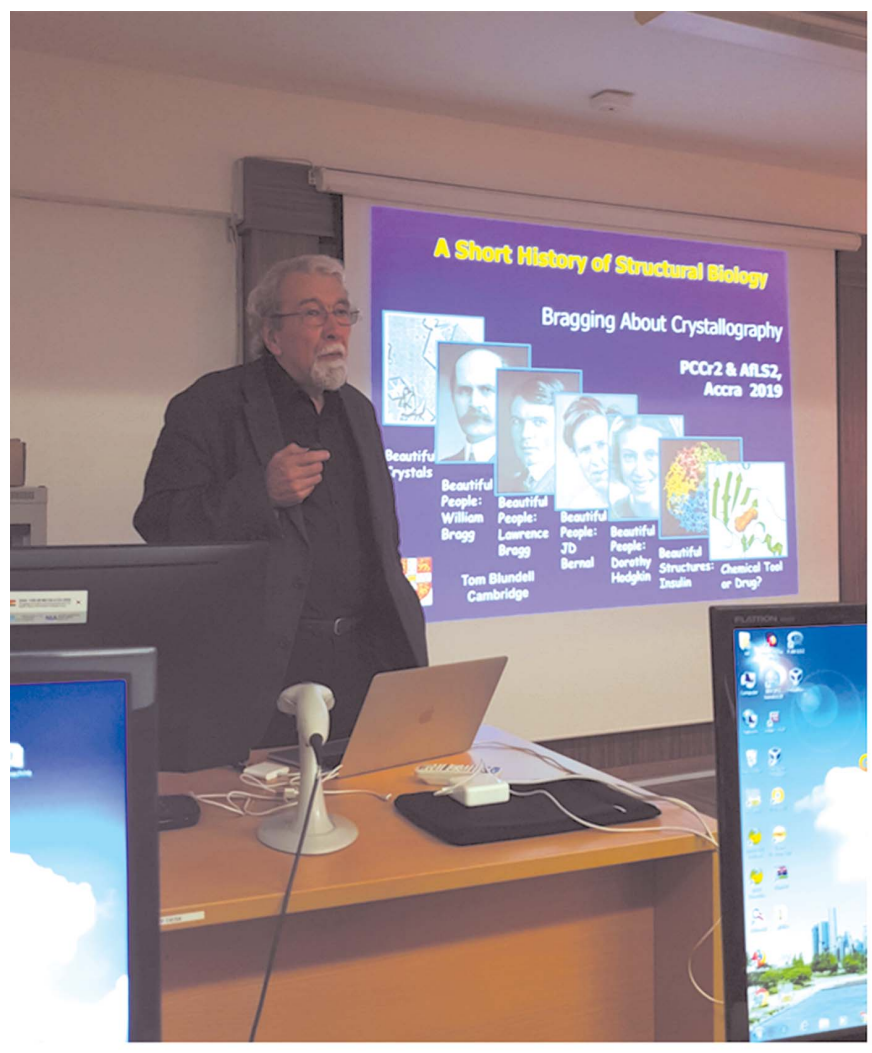

(a)

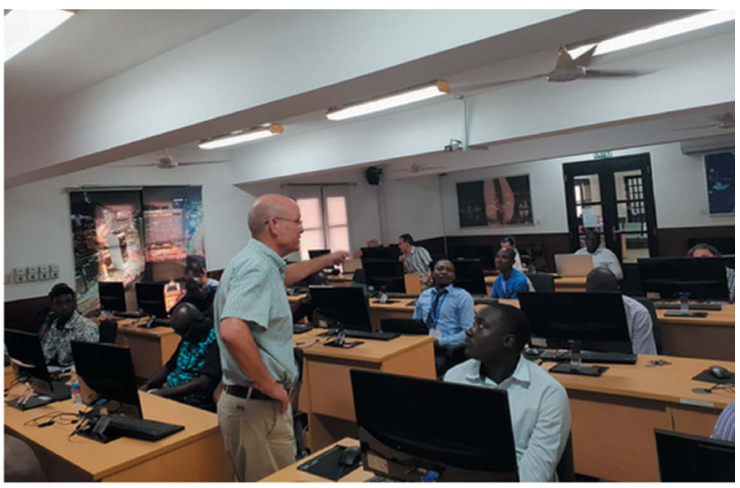

(b)

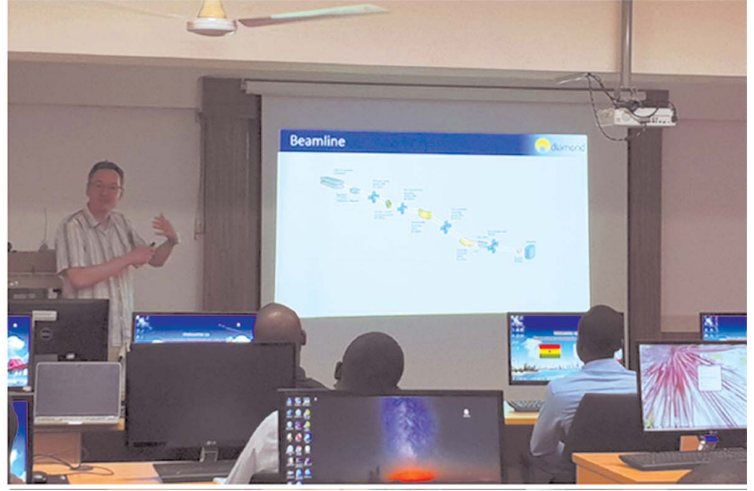

(c)

Figure 1

BioStruct-Africa introductory lectures by (a) Professor Sir Tom Blundell, (b) Professor Wolf-Dieter Schubert and (c) Dr Ralf Flaig.

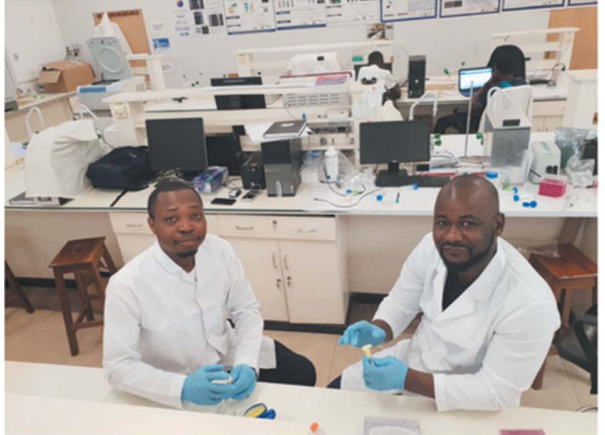

(a)

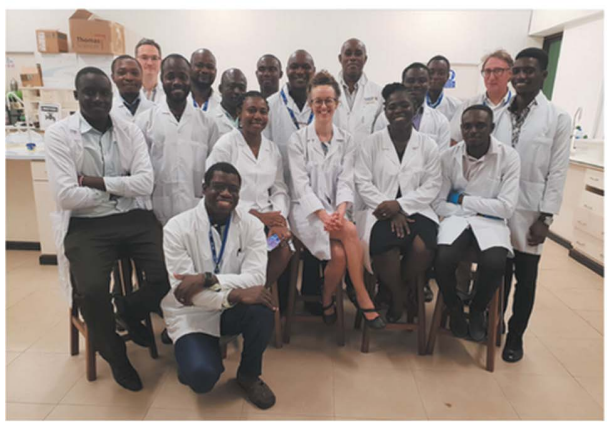

(b)

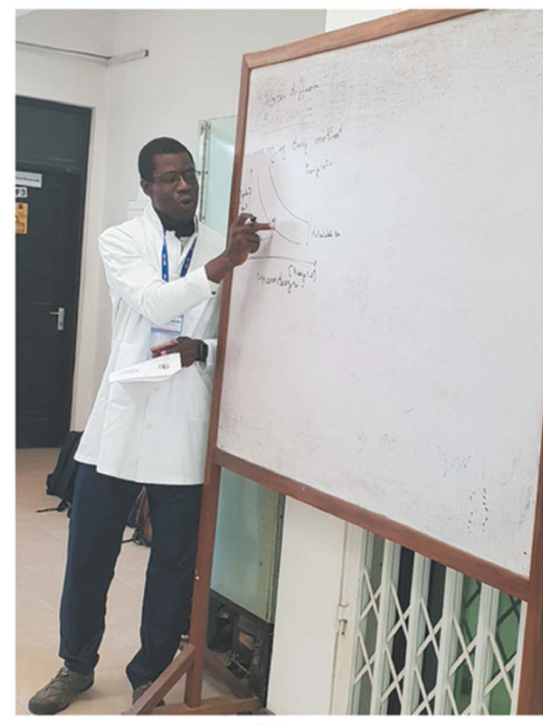

(c)

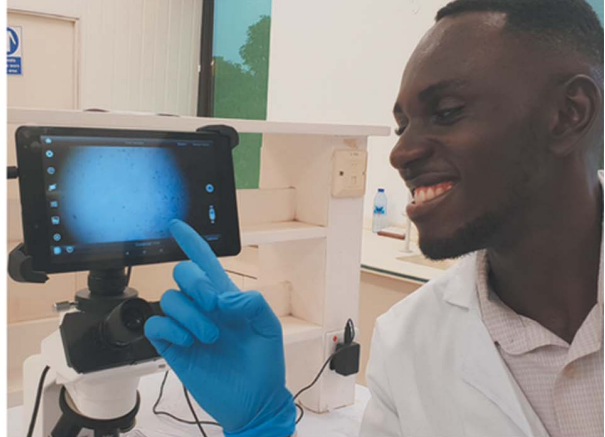

(d)

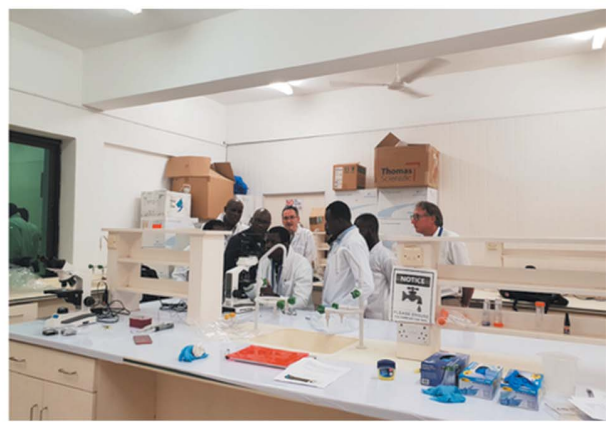

(e)

Figure 2

Hands-on training in protein crystallization, crystal imaging, cryo-cooling and harvesting. (a) Mama Ndi (left) and Dr Emmanuel Nji (right) setting up the protein production laboratory at the Department of Biochemistry, University of Ghana. (b) Hands-on training group photograph including participants and the BioStruct-Africa team. $(c)$ Dr Daouda Traore introducing the concepts of vapour diffusion crystallization. $(d)$ Watching protein crystals grow in real time. (e) Participants visualizing protein crystals under the microscope. 


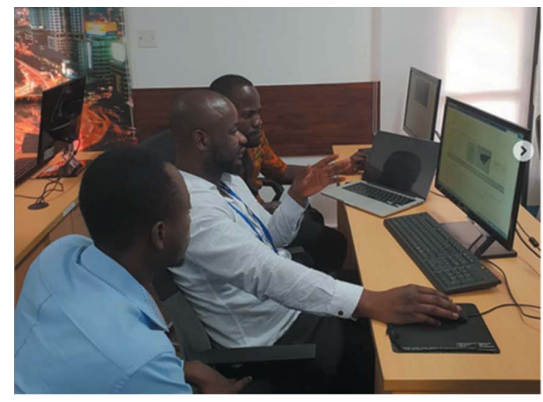

(a)

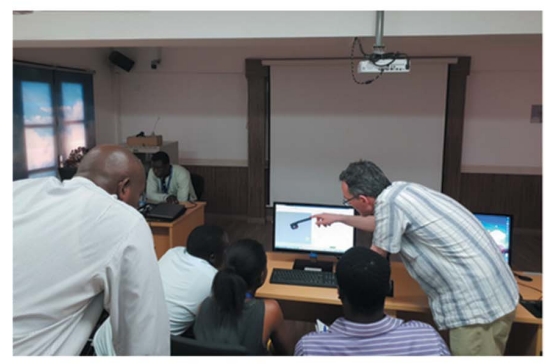

(b)

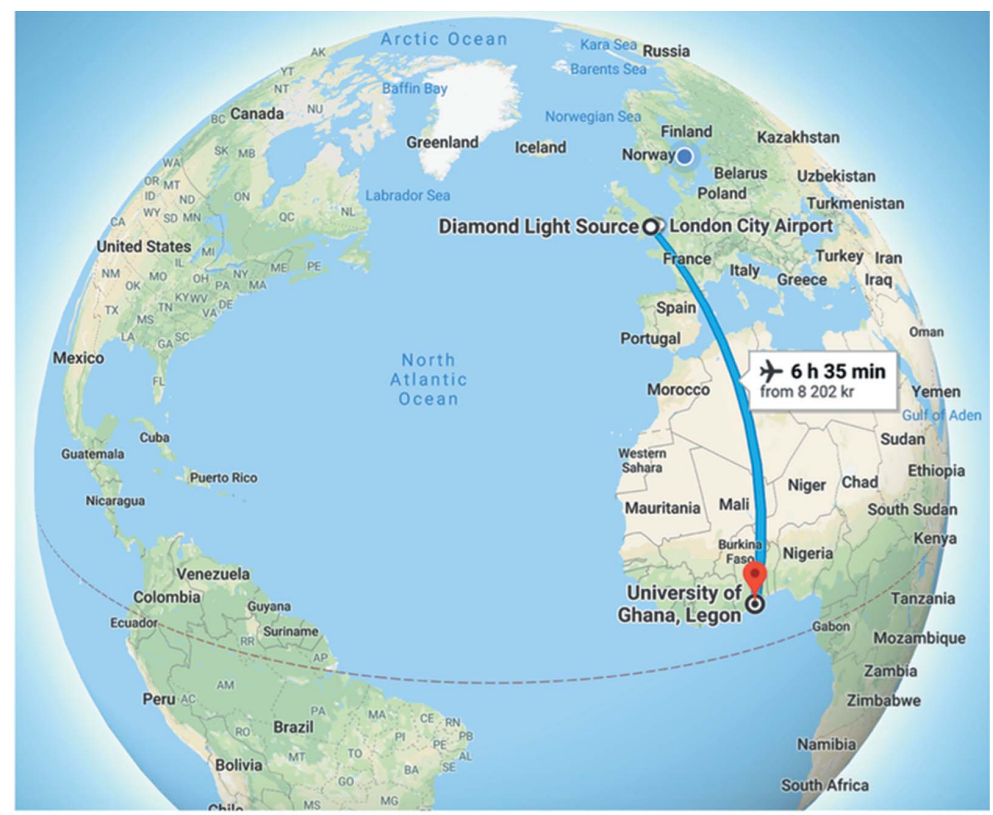

(c)

Figure 3

Hands-on training in synchrotron remote data collection. The demonstrators were $(a)$ Dr Emmanuel Nji and $(b)$ Dr Ralf Flaig. (c) Data were collected by linking the University of Ghana and the MX beamline I04 at DLS Ltd, UK.

tive, one week prior to the start of the workshop, BioStructAfrica members Dr Emmanuel Nji and Mr Mama Ndi organized and set up the laboratory [Fig. 2(a)]. The final part was remote data collection, linking the University of Ghana and DLS, UK (Fig. 3).

\subsection{Measuring impacts and achievements}

After completing the workshop, all participants were asked to fill out an anonymous electronic evaluation survey using SurveyMonkey (San Mateo, CA, USA; https://www.survey monkey.com). In all questions asked (for example, Overall, were you satisfied or dissatisfied with the workshop? How clear were the instructions before starting the workshop? How clearly did the demonstrators explain the procedure during the practical?), none of the answers were negative, demonstrating the success of this approach and the desire for the participants to receive such training. Overall, 50\% said they were very satisfied and the remaining $50 \%$ said they were satisfied with the workshop (Fig. 4). To improve future workshops, participants provided suggestions such as extend the training over a number of days to give time for participants to learn effectively, repeat the workshop annually and increase the tutor/student contact time (Fig. 4). Overall, the workshop was a huge success. We were able to grow protein crystals by hanging-drop vapour diffusion and could connect to DLS, UK, and collect data from crystals grown at DLS. We are very satisfied with the evaluations from the workshop and this will serve as a guide for future workshops. In addition, the workshop resulted in two new researchers from Nigeria being added to the BioStruct-Africa team which is in line with our strategic plans to have a continuous growing network of African structural biologists.

\section{Future perspectives}

4.1. BioStruct-Africa road map towards the realization of the African Light Source project

Africa is the only continent that does not have a synchrotron light source (Connell et al., 2018). This is partly due to the requirement of substantial human and financial resources which has discouraged governments, private institutions, researchers, scientists and students from embarking on such an ambitious goal. However, it has been recognized that building a light source in Africa would have enormous socio-economic benefits for the continent (Connell et al., 2018). The most striking benefits would be the ability to fully target diseases affecting Africa through protein crystallography, the promotion of collaborations, the retention of highly skilled Africans and the motivation of the Africans conducting cutting-edge research in the diaspora to return home and contribute to solving the problems affecting their home countries (Connell et al., 2018).

In this light, the first African Light Source (AfLS) conference was held at the European Synchrotron Radiation Facility, Grenoble, France, on 16-20 November, 2016, to discuss a roadmap towards the realization of the first AfLS (Connell et al., 2018). One of the main aims was to train Africa-based researchers to be able to make use of a synchrotron light source when it comes into existence on the continent (Connell et al., 2018). BioStruct-Africa has started this training process in line with the AfLS project, which seeks to empower African scientists through knowledge transfer and mentoring using cutting-edge techniques in structural biology while the African continent finds the resources to build its own synchrotron light source. With this in mind, BioStruct-Africa will have trained a significant number of researchers ready to take full advantage 

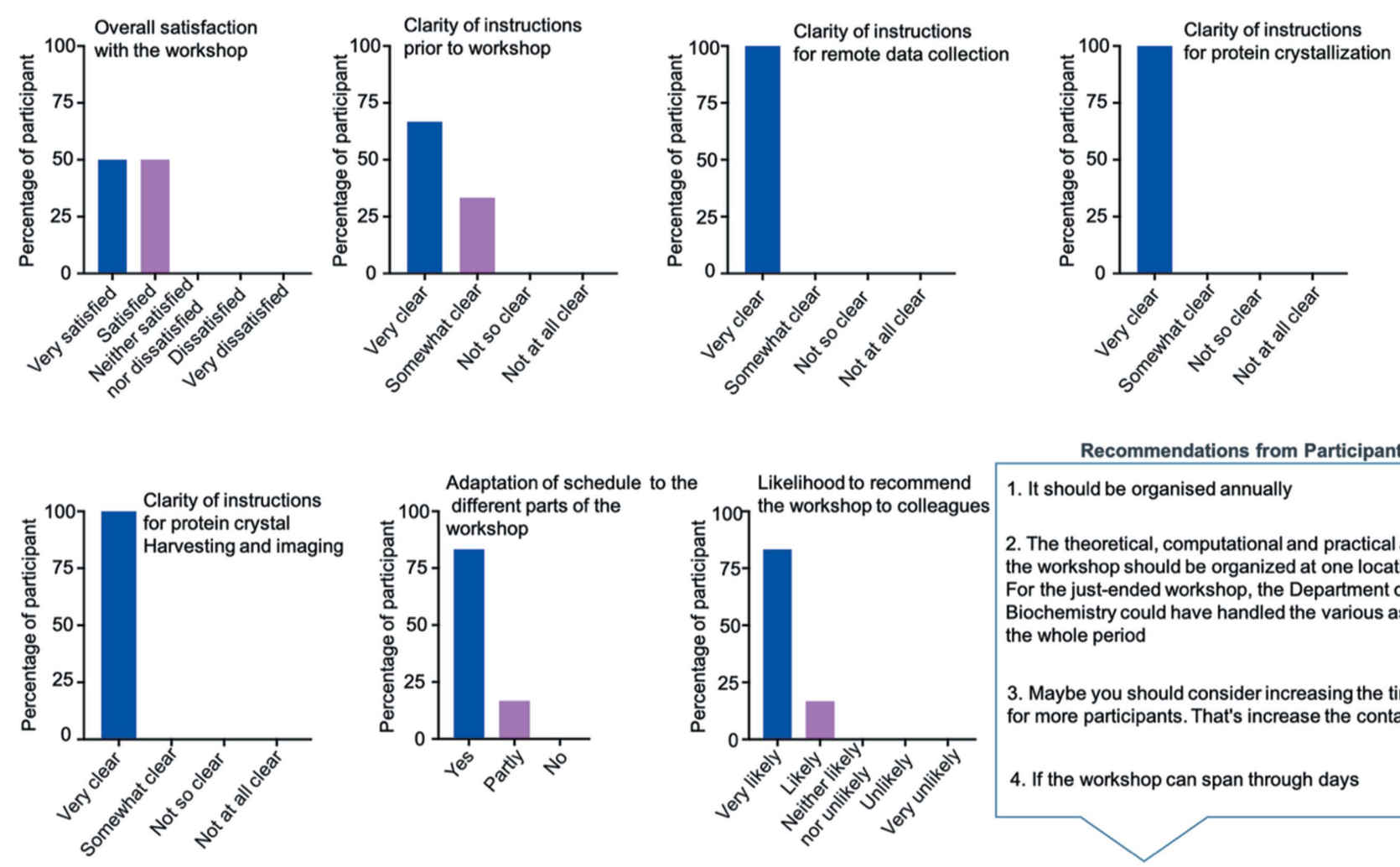

Recommendations from Participants

1. It should be organised annually

2. The theoretical, computational and practical aspects of the workshop should be organized at one location. E.g. For the just-ended workshop, the Department of Biochemistry could have handled the various aspects for the whole period

3. Maybe you should consider increasing the time to cater for more participants. That's increase the contact time.

4. If the workshop can span through days

Figure 4

Feedback report from the BioStruct-Africa workshop, University of Ghana, Accra, Ghana, January 2019.

of such a facility. BioStruct-Africa is excited to be at the forefront of this multidisciplinary, multilingual and multicultural endeavour.

4.1.1. Our potential. In less than two years, BioStructAfrica has rapidly identified and formed a robust team of experts including, but not limited to, structural biologists working and studying in some of the best universities and research institutes around the world. In the future, BioStructAfrica will expand to be a multi-disciplinary organization that has structural biology at the heart of its approach. To date, our multidisciplinary team comprises:

(i) Experts in protein production, crystallization, data collection and data processing, with proven track records based on publications in high-impact scientific journals (e.g. Nji et al., 2018; Traore et al., 2018; Coincon et al., 2016; Uzdavinys et al., 2017; Lang et al., 2018; Nji et al., 2014, 2019; Lee et al., 2014; Moure et al., 2019; D’Avanzo et al., 2010; Soundararajan et al., 2008; Yang et al., 2006; Kuo et al., 2003).

(ii) Bioinformaticians, which include experts in in silico analyses of possible protein targets, dynamic simulations and modelling.

(iii) Cellular and molecular biologists with expertise in several applicable techniques in cellular and molecular biology research (Heublein et al., 2019; Ndi et al., 2018).

(iv) Global and public health scientists, including experts who understand how structural biology can be applied in realizing the SDGs. (v) Social and political scientists, including experts in project management. We envisage that they will serve as connectors between BioStruct-Africa and local politicians/ leaders for the implementation of evidence-based research.

4.1.2. Awareness. We recognized that there are more specialized schools focusing on training structural biologists such as CCP4, Erice and EMBL; however, these are adapted for advanced scientists and require the funds to be able to travel abroad in order to attend. The BioStruct-Africa workshop and short-term goal is to show students and researchers that structural biology can be done in Africa and provide a stepping stone for those who wish to continue in that direction.

Our agenda is to use local television and radio programs to demonstrate to Africans the importance of taking control of and leading the research against diseases. By doing so, this will help to dispel the mindset and distrust that unfortunately exists. Many believe that westerners only come in to deliver medicine during health crises solely for their benefit and not the long-term benefit of the local people. Ebola is a good example in which people were attacking Ebola clinics as local people believed they were the ones spreading the disease (Ratcliffe, 2019). In the future, we also intend to visit high schools and demonstrate protein crystallization and teach the beauty and importance of macromolecular structural biology. Ultimately, we envisage the use of 3D-printing technologies for teaching and instruction, again using advances in tech- 
nology for knowledge transfer. Through our outreach programme, BioStruct-Africa will establish clubs at high schools to contribute to STEM education for young aspiring scientists.

4.1.3. Partnership. BioStruct-Africa is creating partnerships with governmental and non-governmental institutions around the world, especially in Africa. So far, we have an established working relationship with the University of Ghana, the University of the Witwatersrand (Johannesburg), the International Centre for Insect Physiology and Ecology, ICIPE (Nairobi, Kenya), the University of Namibia, the University of Malawi, College of Medicine, Ethiopian Biotechnology Institute; many others have already expressed interest in our initiative. We have heads of research groups in our partner universities working with us to facilitate training workshops by providing working spaces, equipment and teaching aids for participants. We also have country coordinators representing BioStruct-Africa responsible for local mobilization and informing local researchers about our vision. Through our online portal (https://www.biostructafrica.org), potential workshop participants are requested to register ahead of time for proper planning and execution.

BioStruct-Africa intends to foster collaboration and mutually beneficial networks between our partner universities in Africa and the rest of the world. In the long term, the organization intends to nurture the movement of researchers through scientific exchange placements and training programmes within partner universities to further the development of the scientists. In addition, it is our aim to work in collaboration with the partner universities to design and develop a curriculum for Masters/PhD degree programmes in structural biology.

4.1.4. Sponsorship, funding and the way forward. We would like to give our appreciation to The Company of Biologists and the Royal Society of Chemistry, Chemical and Biology Interface Division for sponsoring the BioStructAfrica workshop 2019 in Accra, Ghana, and the University of Ghana for providing rooms and facilities. Whilst our existing human resources and partner institutions are readily available, we are working hard through groups, institutions, NGOs and governments to promote our vision through financial donations. We are also talking with synchrotron sources to create a Block Allocation Group (BAG) time for BioStruct-Africa for remote data collection during our workshops and for when structural biology begins to bear fruit in African research institutes.

Lastly, we are working with funding bodies to provide startup grants for BioStruct-Africa members in the diaspora to relocate back to Africa in order to work on solving the structures of proteins that are relevant to diseases plaguing the continent. Indeed, this will not only make laboratories readily available to train students, thereby ensuring sustainable capacity building, but also provide the starting material that will be exploited to screen small-molecule compound libraries for drug discovery. The GFP-TS assay, developed by Dr Emmanuel Nji (CEO and co-founder of BioStruct-Africa) and others, which has been used to screen small molecules/ ligands and lipids for medically relevant proteins in a highthroughput manner (Nji et al., 2018), is a clear example of an assay that can be used for such purpose.

\section{Conclusions}

'The goal of BioStruct-Africa is to train, develop and maintain world-class structural biologists working in Africa in order to combat diseases affecting the continent and aid global health initiatives. Due to interconnectivity, climate change and the movement of people for socio-economic reasons, some diseases, typically constrained to Africa, are beginning to spread beyond Africa's borders. The rise of antibiotic resistance is a clear example of a serious global health crisis that needs to be tackled immediately by all countries in the world' (Aslam et al., 2018; Lawrence \& Jeyakumar, 2013; Gootz, 2010).

'Investing to expand an organization such as BioStructAfrica to train Africa-based researchers to work on NTDs, HIV/AIDS and malaria is neither a waste of resources nor time. As a result of evolution, biological life is fundamentally connected. Hence, uncovering the molecular details underpinning any disease has benefits for all other diseases. Structural biology is an essential tool for pushing forward our understanding of all biological processes, providing the molecular details of disease intervention points, aiding smallmolecule drug development and antibody development' (https://www.biostructafrica.org). We welcome any individual or organisation that wishes to contribute towards the realisation of BioStruct-Africa's vision to contact us at https:// www.biostructafrica.org.

\section{Acknowledgements}

We would like to thank Professor Sir Tom Blundell, Dr Ralf Flaig, Professor Wolf-Dieter Schubert, Professor Richard Garratt, Cecilia Brenner, Dr Amma Aboagyewa Larbi and The Department of Biochemistry, University of Ghana for their participation and help in the workshop.

\section{Funding information}

The following funding is acknowledged: The Company of Biologists Ltd, UK (grant No. EA1750); The Royal Society of Chemistry, Chemical and Biology Interface Division (grant No. T18-000AA).

\section{References}

Acharya, T., Kennedy, R., Daar, A. S. \& Singer, P. A. (2004). Mem. Inst. Oswaldo Cruz, 99, 341-350.

Addaney, M. (2018). Education Law, Strategic Policy and Sustainable Development in Africa, edited by A. C. Onuora-Oguno, W. O. Egbewole \& T. E. Kleven, pp. 181-197. Cham: Springer.

Addisu, A., Adriaensen, W., Balew, A., Asfaw, M., Diro, E., Garba Djirmay, A., Gebree, D., Seid, G., Begashaw, H., Harries, A. D., Hirpa Adugna, A., Ayalew Jejaw, Z., Kamau, E. M., Kelbo, T., Manzi, M., Medebo Daniel, D., Moloo, A., Olliaro, P., Owiti, P., Reeder, J. C., Senkoro, M., Takarinda, K., Terry, R., Timire, C., 
Tucho, S., Tweya, H., Wendemagegn, Y., Verdonck, K., Vogt, F., van Henten, S., van Griensven, J., Worku, B., Zolfo, M., Zachariah, R. \& Ethiopia SORT IT Neglected Tropical Diseases Group (2019). BMJ Glob. Health, 4, e001334.

Aslam, B., Wang, W., Arshad, M. I., Khurshid, M., Muzammil, S., Rasool, M. H., Nisar, M. A., Alvi, R. F., Aslam, M. A., Qamar, M. U., Salamat, M. K. F. \& Baloch, Z. (2018). Infect. Drug Resist. 11, 1645-1658.

Bangert, M., Molyneux, D. H., Lindsay, S. W., Fitzpatrick, C. \& Engels, D. (2017). Infect. Dis. Poverty, 6, 73.

Cheng, Y., Grigorieff, N., Penczek, P. A. \& Walz, T. (2015). Cell, 161, 438-449.

Coincon, M., Uzdavinys, P., Nji, E., Dotson, D. L., Winkelmann, I., Abdul-Hussein, S., Cameron, A. D., Beckstein, O. \& Drew, D. (2016). Nat. Struct. Mol. Biol. 23, 248-255.

Connell, S. H., Mtingwa, S. K., Dobbins, T., Masara, B. E. P., Mitchell, Norris, L., Ngabonziza, P., Ntsoane, T. \& Sekota, M. (2018). Afr. Rev. Phys. 13, 0019.

Daar, A. S., Berndtson, K., Persad, D. L. \& Singer, P. A. (2007). BMC Public Health, 7, 346.

Daar, A. S., Thorsteinsdóttir, H., Martin, D. K., Smith, A. C., Nast, S. \& Singer, P. A. (2002). Nat. Genet. 32, 229-232.

D'Avanzo, N., Cheng, W. W. L., Xia, X., Dong, L., Savitsky, P., Nichols, C. G. \& Doyle, D. A. (2010). Protein Expr. Purif. 71, 115121.

DESA (2016). The Sustainable Development Goals Report 2016. New York: United Nations.

Diez-Silva, M., Dao, M., Han, J., Lim, C.-T. \& Suresh, S. (2010). MRS Bull. 35, 382-388.

Elguero, E., Délicat-Loembet, L. M., Rougeron, V., Arnathau, C., Roche, B., Becquart, P., Gonzalez, J.-P., Nkoghe, D., Sica, L., Leroy, E. M., Durand, P., Ayala, F. J., Ollomo, B., Renaud, F. \& Prugnolle, F. (2015). Proc. Natl Acad. Sci. USA, 112, 7051-7054.

Fernandez-Leiro, R. \& Scheres, S. H. W. (2016). Nature, 537, 339-346. Fitzpatrick, C. \& Engels, D. (2016). Intl Health, 8(Suppl.1), i15-i18.

Fitzpatrick, C., Nwankwo, U., Lenk, E., de Vlas, S. J. \& Bundy, D. A. P. (2017). Major Infectious Diseases, edited by K. K. Holmes, S. Bertozzi, B. R. Bloom \& P. Jha. Washington, DC: The International Bank for Reconstruction and Development/The World Bank.

Gootz, T. D. (2010). Crit. Rev. Immunol. 30, 79-93.

Heublein, M., Ndi, M., Vazquez-Calvo, C., Vögtle, F.-N. \& Ott, M. (2019). J. Mol. Biol. 431, 1460-1467.

Johnston, K. L., Ford, L. \& Taylor, M. J. (2014). J. Biomol. Screen. 19, 335-343.

Kumwenda, S., Niang, E. H. A., Orondo, P. W., William, P., Oyinlola, L., Bongo, G. N. \& Chiwona, B. (2017). Malawi Med. J. 29, 1-4.

Kuo, A., Gulbis, J. M., Antcliff, J. F., Rahman, T., Lowe, E. D., Zimmer, J., Cuthbertson, J., Ashcroft, F. M., Ezaki, T. \& Doyle, D. A. (2003). Science, 300, 1922-1926.

Lang, T., Lee, J. P. W., Elgass, K., Pinar, A. A., Tate, M. D., Aitken, E. H., Fan, H., Creed, S. J., Deen, N. S., Traore, D. A. K., Mueller, I., Stanisic, D., Baiwog, F. S., Skene, C., Wilce, M. C. J., Mansell, A., Morand, E. F. \& Harris, J. (2018). Nat. Commun. 9, 2223.

Lansche, C., Dasanna, A. K., Quadt, K., Fröhlich, B., Missirlis, D., Tétard, M., Gamain, B., Buchholz, B., Sanchez, C. P., Tanaka, M., Schwarz, U. S. \& Lanzer, M. (2018). Commun. Biol. 1, 211.

Lawrence, R. \& Jeyakumar, E. (2013). BMC Proc. 7, S1.

Lee, C., Kang, H. J., Hjelm, A., Qureshi, A. A., Nji, E., Choudhury, H., Beis, K., de Gier, J.-W. \& Drew, D. (2014). FEBS Lett. 588, 3761-3769.

Ma, B., Shatsky, M., Wolfson, H. J. \& Nussinov, R. (2002). Protein Sci. 11, 184-197.

Miah, M. \& Omar, A. (2012). Int. J. Sci. Appl. Inf. Technol. 1, 30-38.
Mohanty, J. G., Nagababu, E. \& Rifkind, J. M. (2014). Front. Physiol. $\mathbf{5}, 84$.

Moure, V. R., Siöberg, C. L. B., Valdameri, G., Nji, E., Oliveira, M. A. S., Gerdhardt, E. C. M., Pedrosa, F. O., Mitchell, D. A., Seefeldt, L. C., Huergo, L. F., Högbom, M., Nordlund, S. \& Souza, E. M. (2019). FEBS J. 286, 1214-1229.

Ndi, M., Marin-Buera, L., Salvatori, R., Singh, A. P. \& Ott, M. (2018). J. Mol. Biol. 430, 3892-3905.

Nishi, H., Tyagi, M., Teng, S., Shoemaker, B. A., Hashimoto, K., Alexov, E., Wuchty, S. \& Panchenko, A. R. (2013). PLoS One, 8, e66273.

Nji, E., Chatzikyriakidou, Y., Landreh, M. \& Drew, D. (2018). Nat. Commun. 9, 4253

Nji, E., Gulati, A., Qureshi, A. A., Coincon, M. \& Drew, D. (2019). Nat. Struct. Mol. Biol. 26, 415-423.

Nji, E., Li, D., Doyle, D. A. \& Caffrey, M. (2014). Acta Cryst. F70, 1362-1367.

Njim, T. \& Aminde, L. N. (2017). BMC Public Health, 17, 103.

Ratcliffe, R. (2019). Arsonists Attack Ebola Clinics in DRC as Climate of Distrust Grows in The Guardian, https://www.theguardian.com/ global-development/2019/feb/28/arsonists-attack-ebola-clinics-indrc-as-climate-of-distrust-grows.

Reperant, L. A. \& Osterhaus, A. D. M. E. (2017). Vaccine, 35, 44704474.

Singer, P. A., Court, E. B., Bhatt, A., Frew, S. E., Greenwood, H., Persad, D. L., Salamanca-Buentello, F., Séguin, B., Taylor, A. D., Daer, H. T. \& Daar, A. S. (2007). Afr. J. Med. Med. Sci. 36(Suppl.), 7-14.

Singer, P. A. \& Daar, A. S. (2001). Science, 294, 87-89.

Soundararajan, M., Willard, F. S., Kimple, A. J., Turnbull, A. P., Ball, L. J., Schoch, G. A., Gileadi, C., Fedorov, O. Y., Dowler, E. F., Higman, V. A., Hutsell, S. Q., Sundström, M., Doyle, D. A. \& Siderovski, D. P. (2008). Proc. Natl Acad. Sci. USA, 105, 6457-6462.

Stephen, N., Nden, N., Gusen, N., Kumzhi, P., Gaknung, B., Auta, D., Bulndi, L., Mbursa, C., Kumari, V. \& Nanvyat, N. (2018). Acta Med. Intl, 5, 20.

Teng, S., Madej, T., Panchenko, A. \& Alexov, E. (2009). Biophys. J. 96, 2178-2188.

Thorsteinsdóttir, H., Quach, U., Martin, D. K., Daar, A. S. \& Singer, P. A. (2004). Nat. Biotechnol. 22, DC3-DC7.

Traore, D. A. K., Wisniewski, J. A., Flanigan, S. F., Conroy, P. J., Panjikar, S., Mok, Y.-F., Lao, C., Griffin, M. D. W., Adams, V., Rood, J. I. \& Whisstock, J. C. (2018). Nat. Commun. 9, 3732.

UNESCO (2015). Science Report: Towards 2030. Paris: UNESCO Publishing.

United Nations Department of Economic and Social Affairs (2017). The Sustainable Development Goals Report 2017. New York: United Nations.

United Nations Department of Economic and Social Affairs (2018). The Sustainable Development Goals Report 2018. New York: United Nations.

Uzdavinys, P., Coinçon, M., Nji, E., Ndi, M., Winkelmann, I., von Ballmoos, C. \& Drew, D. (2017). Proc. Natl Acad. Sci. USA, 114, E1101-E1110.

Wang, H.-W. \& Wang, J.-W. (2017). Protein Sci. 26, 32-39.

Wei, Q., Wang, L., Wang, Q., Kruger, W. D. \& Dunbrack, R. L. (2010). Proteins, 78, 2058-2074.

WHO. (2002). Genomics and World Health: Report of the Advisory Committee on Health Research. Geneva: World Health Organization.

Yang, X., Lee, W. H., Sobott, F., Papagrigoriou, E., Robinson, C. V., Grossmann, J. G., Sundström, M., Doyle, D. A. \& Elkins, J. M. (2006). Proc. Natl Acad. Sci. USA, 103, 17237-17242.

Yates, C. M. \& Sternberg, M. J. E. (2013). J. Mol. Biol. 425, 3949-3963. 